\title{
Evaluasi Responsivitas Program Kabupaten Sehat Di Kabupaten Blitar
}

\author{
Handy Twinosa dan Agam Marsoyo \\ Universitas Gadjah Mada \\ e-mail: handy.twinosa@gmail.com
}

\begin{abstract}
Abstrak-Program Kabupaten Sehat adalah suatu kondisi kabupaten yang bersih, nyaman, aman dan sehat untuk dihuni penduduk, dicapai melalui terselenggaranya penerapan beberapa tatanan dan kegiatan yang terintegrasi yang disepakati masyarakat dan pemerintah daerah. Pelaksanaan Kabupaten Sehat di Kabupaten Blitar diwujudkan dengan menyelenggarakan semua program yang menjadi permasalahan di Kabupaten Blitar secara bertahap, dimulai kegiatan perioritas bagi masyarakat di sejumlah kecarnatan pada sejumlah desal kelurahan atau bidang usaha yang bersifat sosial ekonomi dan budaya di kawasan tertentu. Penelitian ini bertujuan untuk mengidentifikasi hasil evaluasi responsivitas masyarakat terhadap Program Kabupaten Sehat. Penelitian ini berlokasi di 14 Kecamatan di Kabupaten Blitar yang terdampak langsung Program Kabupaten Sehat. Pendekatan penelitian responsivitas Program Kabupaten Sehat di Kabupaten Blitar menggunakan alur pemikiran deduktif kuantitatif dan kualitatif.teknik analisis menggunakan statistik deskriptif serta teknik analisis kualitatif. Sampel penelitian adalah rumah tangga di 14 Kecamatan yang terdampak Program Kabupaten Sehat secara langsung sebanyak 348 rumah tangga. Temuan penelitian memperlihatkan bahwa Program Kabupaten Sehat telah memenuhi kriteria responsivitas. Namun, masih terdapat beberapa warga yang belum berperan dalam Program Kabupaten Sehat dikarenakan akses terhadap infomasi mengenai kegiatan-kegiatan yang dilakukan masih terbatas. Selain itu, mereka juga masih bersifat pasif dengan menganggap suatu program yang dilakukan oleh pemerintah adalah tanggung jawab pemerintah itu sendiri.
\end{abstract}

Kata Kunci- evaluasi, program kabupaten sehat, responsivitas

\section{PENDAHULUAN}

$\mathrm{P}$ ENELITIAN mengenai evaluasi responsivitas Program Kabupaten Sehat di Kabupaten Blitar dengan fokus dan lokasi yang sama belum pernah dilakukan. Beberapa penelitian terkait evaluasi implementasi program yang telah dilakukan memiliki fokus yang berbeda, seperti: evaluasi terhadap program penanggulangan bencana, program air bersih, program pengelolaan sampah, program perbaikan perumahan, dan program transmigrasi. Selain itu, penelitian di lokasi yang sama, yaitu Kabupaten Blitar belum pernah dilakukan.

Kabupaten Blitar merupakan daerah dengan luas wilayah yang cukup besar sehingga menjadikan daerah ini salah satu daerah dengan potensi kesenjangan dalam pembangunan daerah khususnya dalam hal pembangunan pemenuhan kebutuhan dasar manusia seperti jamban, instalasi pengolahan air limbah (IPAL), taman kota, sarana pengolahan sampah, dan penyediaan sungai bersih. Beberapa program pemerintah dalam mengatasi pemenuhan kebutuhan dasar masyarakat hanya terkonsentrasi di pusat perkotaan wilayah. Beberapa kecamatan yang memiliki lokasi yang berjauhan dengan pusat perkotaan seringkali belum terjangkau oleh program dari pemerintah.

Salah satu upaya Pemerintah Kabupaten Blitar dalam meningkatkan kualitas hidup masyarakat adalah dengan melaksanakan Program Kabupaten Sehat. Menurut Permendagri dan Menkes No. 34 tahun 2005, Program Kabupaten Sehat adalah suatu kondisi kabupaten yang bersih, nyaman, aman dan sehat untuk dihuni penduduk, dicapai melalui terselenggaranya penerapan beberapa tatanan dan kegiatan yang terintegrasi yang disepakati masyarakat dan pemerintah daerah. Tujuan dari penyelenggaraan Kabupaten Sehat adalah mewujudkan suatu kawasan sehat. Kawasan sehat menurut Permendagri dan Menkes No. 34 tahun 2005 adalah suatu kondisi wilayah yang bersih, nyaman, aman dan sehat bagi pekerja dan masyarakat.

Program Kabupaten Sehat telah dilaksanakan di Kabupaten Blitar sejak tahun 2012. Tujuan utama pelaksanaan program ini adalah untuk meningkatkan kualitas hidup masyarakat di Kabupaten Blitar yang dinilai dari beberapa aspek seperti aspek kesehatan, pendidikan dan ekonomi masyarakat. Pengukuran ketiga aspek ini dapat digambarkan melalui Indeks Pembangunan Manusia (IPM). Berikut adalah IPM Kabupaten Blitar.

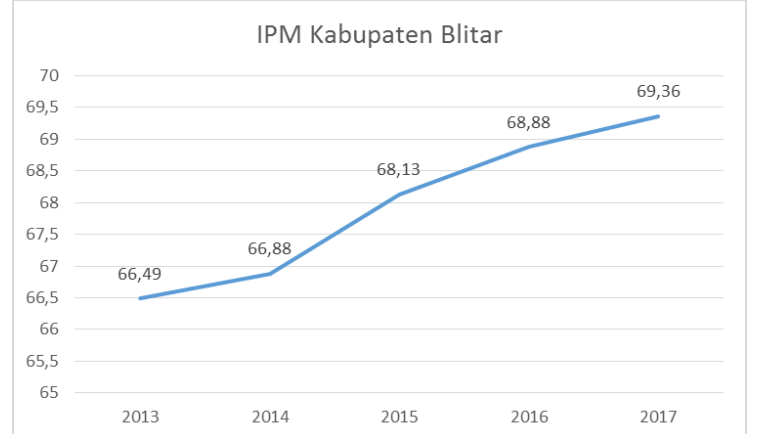

Gambar 1. IPM Kabupaten Blitar

Dari gambar di atas dapat diketahui bahwa IPM Kabupaten Blitar selalu mengalami peningkatan sejak tahun 2013. Namun, meskipun ada peningkatan setiap tahunnya, IPM Kabupaten Blitar masih berada di bawah IPM Jawa Timur dan Nasional tahun 2017 yaitu sebesar 69,74 untuk IPM Jawa Timur dan 70,81 untuk IPM nasional.

Dengan kondisi wilayah Kabupaten Blitar yang cukup luas, implementasi Program Kabupaten Sehat dihadapkan dengan permasalahan jangkauan pelayanan program yang belum mampu menjangkau seluruh wilayah. Suatu kebijakan publik dianggap berhasil jika dapat diimplementasikan dengan baik di dalam masyarakat. Mazmanian dan Sabatier dalam Agustino (2008) berpendapat bahwa peran penting dari implementasi kebijakan publik adalah kemampuan 
dalam mengidentifikasikan variabel-variabel yang mempengaruhi tercapainya tujuan-tujuan formal pada keseluruhan proses implementasi. Kebijakan publik menurut Islamy (2009) adalah serangkaian tindakan yang mempunyai tujuan tertentu yang diikuti dan dilaksanakan oleh seorang pelaku atau sekelompok pelaku guna memecahkan suatu masalah tertentu.

Oleh karena itu, berdasarkan latar belakang kondisi Program Kabupaten Sehat yang dilaksanakan di Kabupaten Blitar, maka penulis memandang perlu dilakukan evaluasi implementasi Program Kabupaten Sehat yang lebih luas cakupannya dan lebih bersifat sumatif. Hal ini berarti bahwa evaluasi yang dilakukan meninjau hasil Program Kabupaten Sehat dengan berdasarkan pada kriteria evaluasi yang telah dirumuskan oleh beberapa pakar. Nugroho (2012) mengatakan bahwa evaluasi akan memberikan informasi yang valid dan dapat dipercaya mengenai kinerja kebijakan yaitu seberapa jauh kebutuhan, nilai dan kesempatan yang telah dicapai melalui tindakan publik.

Keberhasilan atau kegagalan dari pelaksanaan Program Kabupaten Sehat akan menjadi pelajaran penting untuk merumuskan program yang lebih baik di masa yang akan datang.

Tujuan penelitian ini adalah mengevaluasi hasil (output) pelaksanaan Program Kabupaten Sehat di Kabupaten Blitar berdasarkan kriteria penilaian responsivitas.

\section{METODE PENELITIAN}

\section{A. Jenis dan Pendekatan Penelitian}

Pendekatan penelitian ini menggunakan alur pemikiran deduktif. Penelitian ini termasuk ke dalam penelitian evaluasi (evaluation reasearch) yang bersifat deskriptif dan berdasarkan bentuk data temasuk dalam penelitian kuantitatif dan kualitatif. Hal ini dikarenakan untuk mengkaji evaluasi responsivitas Program Kabupaten Sehat di Kabupaten Blitar diperlukan suatu kajian secara mendalam dengan menggunakan data kuantitatif dan kualitatif. Menurut Sugiyono (2014) menyatakan bahwa penelitian evaluasi merupakan bagian dari evaluasi dan juga merupakan bagian dari penelitian. Sedangkan evaluasi kebijakan publik menurut Muhadjir dalam Widodo (2008), merupakan suatu proses untuk menilai seberapa jauh suatu kebijakan publik dapat membuahkan hasil, yaitu dengan membandingkan antara hasil yang diperoleh dengan tujuan atau target kebijakan publik yang ditentukan.

\section{B. Variabel Penelitian}

Subjek penelitian adalah Program Kabupaten sehat yang terdiri dari tiga kegiatan, yaitu: (1) Kegiatan Sanitasi Total Berbasis Masyarakat (STBM); (2) Kegiatan Instalasi Pengolahan Air Limbah (IPAL) Komunal Berbasis Masyarakat; dan (3) Kegiatan Penanganan Sampah.

Menurut Arikunto (2010), metode pengambilan sampel (sampling method) digunakan agar diperoleh sampel-sampel penelitian yang benar-benar dapat menggambarkan keadaan populasi. Dalam melakukan pengambilan sampel kuantitatif, peneliti melakukan 2 tahap, yaitu: (1) Metode gugus sederhana (simple cluster sampling) yang digunakan untuk memilih kecamatan sebagai lokasi sampel yang menjadi lokasi Program Kabupaten Sehat. Hasil dari metode gugus sederhana adalah dipilih sebanyak 14 kecamatan yang menjadi lokasi pelaksanaan Program Kabupaten Sehat; dan (2) Menggunakan metode acak sederhana (simpel random sampling) untuk memilih rumah tangga (RT) sebagai sampel penelitian. Besaran sampel ditetapkan berdasarkan tabel penentuan jumlah sampel yang dikembangkan oleh Isaac dan Michael dalam Sugiyono (2011). Dengan jumlah populasi 244252 maka berdasarkan tabel Isaac dan Michael dengan pembulatan ke atas yaitu pada jumlah 250000 dan asumsi tingkat kesalahan sebesar 5\% ditetapkan jumlah sampel sebanyak 348 .

Variabel penelitian menurut Sugiyono (2011) adalah segala sesuatu yang berbentuk apa saja yang ditetapkan oleh peneliti untuk dipelajari sehingga diperoleh informasi tentang hal tersebut, kemudian ditarik kesimpulannya. Variabel yang digunakan dalam penelitian ini diperoleh dari kriteria responsivitas dari penelitian evaluasi program karena fokus evaluasi yang dilakukan adalah dengan melihat responsivitas masyarakat terhadap Program Kabupaten Sehat. Menurut Dwiyanto (2014), responsivitas adalah daya tanggap penyedia layanan terhadap harapan, keinginan, aspirasi maupun tuntutan pengguna layanan. Program Kabupaten Sehat merupakan program yang dijalankan oleh pemerintah dengan melibatkan masyarakat. Oleh karena itu, respon dan peran masyarakat sangat diperlukan dalam menentukan keberhasilan Program Kabupaten Sehat di Kabupaten Blitar. Menurut Arisandi (2012) respon merupakan reaksi terhadap stimulus yang terbatas pada perhatian persepsi, pengetahuan, kesadaran dan sikap yang terjadi pada orang yang menerima stimulus. Sedangkan peran menurut Bakir (2009) adalah sebagai perangkat tingkah yang diharapkan dimiliki oleh orang yang berkedudukan di masyarakat. Sehingga variabel yang sesuai untuk kriterian respnsivitas adalah respon dan peran. Analisis data pada penelitian ini menggunakan analisis statistik deskriptif untuk mengolah data hasil kuisioner, serta analisis kualitatif untuk mengolah data hasil wawancara. Kriteria dan variabel peneitian dijabarkan dalam tabel sebagai berikut..

Tabel 1.

Kriteria dan Variabel Penelitian

\begin{tabular}{|c|c|c|}
\hline $\begin{array}{l}\text { Kriteria } \\
\text { Evaluasi }\end{array}$ & Variabel & Indikator \\
\hline \multirow[t]{2}{*}{$\begin{array}{l}\text { Responsivi } \\
\text { tas }\end{array}$} & $\begin{array}{l}\text { Respon } \\
\text { Masyarakat }\end{array}$ & $\begin{array}{l}\text { Persentase responden yang } \\
\text { menyetujui program kabupaten sehat } \\
\text { lebih besar daripada yang tidak } \\
\text { menyetujui. }\end{array}$ \\
\hline & $\begin{array}{l}\text { Peran Serta } \\
\text { Masyarakat }\end{array}$ & $\begin{array}{l}\text { Persentase responden yang berperan } \\
\text { terhadap program kabupaten sehat } \\
\text { lebih besar daripada yang tidak } \\
\text { berperan. }\end{array}$ \\
\hline
\end{tabular}

\section{HASIL DAN PEMBAHASAN}

Hasil analisis data penelitian berupa data kuantitatif dilakukan melalui metode statistik deskriptif Selanjutnnya, hasil analisis kuantitatif diperbandingan dengan setiap indikator di dalam kriteria evaluasi. Setelah memperoleh hasil perbandingan antara data kuantitatif dan indikator dalam kriteria evaluasi, kemudian dilakukan penggalian informasi lebih mendalam dengan menggunakan analisis 
kualitatif. Analisis kualitatif diharapkan mampu memberikan gambaran secara detail terhadap fenomena khusus dari kejadian suatu variabel yang belum memenuhi indikator evaluasi.

Evaluasi Responsivitas Program Kabupaten Sehat di Kabupaten Blitar

1. Evaluasi Responsivitas Kegiatan Sanitasi Total Berbasis Masyarakat

a. Respon Masyarakat Terhadap Kegiatan Sanitasi Total Berbasis Masyarakat

Respon masyarakat terhadap Kegiatan Sanitasi Total Berbasis Masyarakat (STBM) yang dimaksud adalah pernyataan setuju atau tidak setuju masyarakat terhadap kegiatan yang dilakukan di kecamatan mereka. Hasil evaluasi variabel respon masyarakat terhadap Kegiatan STBM disajikan dalam grafik berikut :

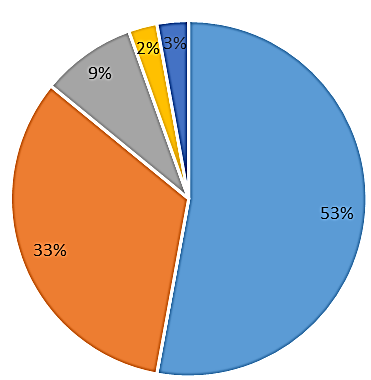

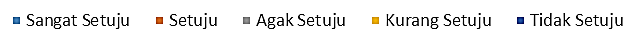

Gambar 2. Respon Masyarakat terhadap Kegiatan Sanitasi Total Berbasis Masyarakat

Hasil analisis statistik deskriptif memperlihatkan bahwa sebagian besar masyarakat menyetujui Kegiatan STBM dilaksanakan di masing-masing kecamatan. Hal ini dapat dilihat dari data temuan bahwa $95 \%$ responden (hasil penjumlahan dari 53\% sangat setuju, 33\% setuju, dan 9\% agak setuju) dapat dikategorikan sebagai masyarakat yang menyetujui adanya kegiatan tersebut.

Kesimpulan dari pembahasan evaluasi respon masyarakat terhadap Kegiatan STBM telah memenuhi indikator evaluasi. Masyarakat merasa terbantu dengan adanya perbaikan jaringan sanitasi di masing-masing kecamatan.

b. Peran Masyarakat Terhadap Kegiatan Sanitasi Total

Berbasis Masyarakat

Penilaian mengenai peran masyarakat terhadap Kegiatan Sanitasi Total Berbasis Masyarakat (STBM) digunakan untuk mengetahui gambaran sejauh mana tindak lanjut dari respon masyarakat terhadap Kegiatan STBM. Peran yang dimaksud adalah segala bentuk keterlibatan masyarakat dalam menjalankan kegiatan pada masing-masing tahapan (perencanaan, pelaksanaan, serta operasi dan pemanfaatan).

Evaluasi variabel peran masyarakat dilakukan dengan melihat gambaran seberapa besar persentase responden yang berperan atau tidak dalam Kegiatan STBM. Hasil evaluasi Kegiatan STBM dengan menggunakan variabel peran masyarakat adalah sebagai berikut :

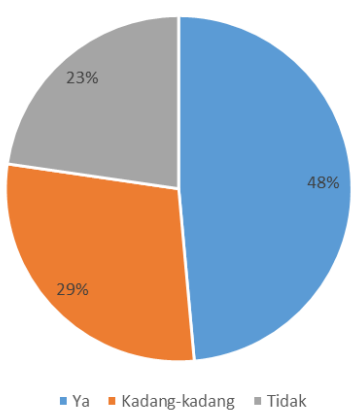

Gambar 3. Peran Masyarakat terhadap Kegiatan Sanitasi Total Berbasis Masyarakat

Hasil analisis statistif deskriptif menunjukkan bahwa sebagian besar responden berperan dalam Kegiatan STBM. Sebanyak $68 \%$ reponden ikut berperan dalam kegiatan tersebut. Sisanya, $29 \%$ responden hanya berperan di beberapa tahapan kegiatan saja dan $23 \%$ responden tidak ikut berperan dalam kegiatan STBM.

Kesimpulan yang bisa didapatkan dari evaluasi Kegiatan STBM menggunakan vaiabel peran masyarakat adalah sudah memenuhi kriteria indikator evaluasi. namun, peran masyarakat masih bersifat pasif dengan kecenderungan hanya menerima saja terhadap kegiatan yang dilakukan di masing-masing kecamatan.

2. Evaluasi Responsivitas Kegiatan Instalasi Pengolahan Air Limbah (IPAL) Komunal Berbasis Masyarakat

a. Respon Masyarakat Terhadap Kegiatan Instalasi Pengolahan Air Limbah (IPAL) Komunal Berbasis Masyarakat.

Respon masyarakat terhadap Kegiatan Instalasi Pengolahan Air Limbah (IPAL) Komunal Berbasis Masyarakat yang dimaksud adalah pernyataan setuju atau tidak setuju masyarakat terhadap kegiatan yang dilakukan di kecamatan mereka. Hasil evaluasi variabel respon masyarakat terhadap Kegiatan Instalasi Pengolahan Air Limbah (IPAL) Komunal Berbasis Masyarakat disajikan dalam grafik berikut:

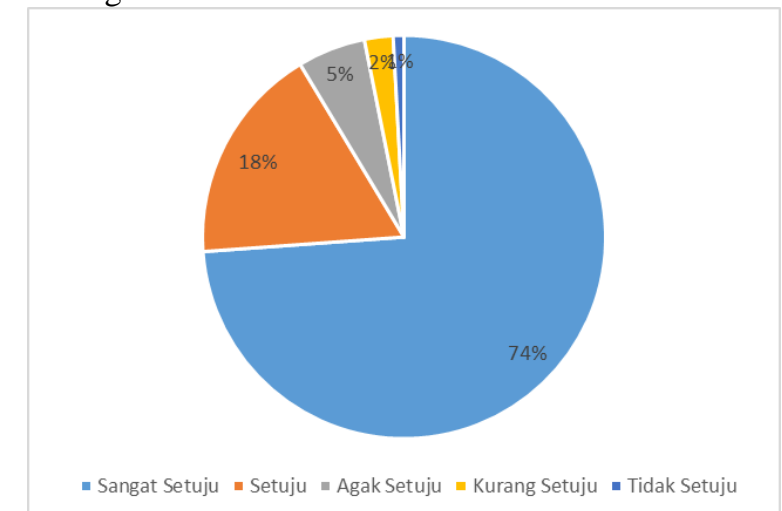

Gambar 4. Respon Masyarakat Terhadap Kegiatan Instalasi Pengolahan Air Limbah (IPAL) Komunal Berbasis Masyarakat

Hasil analisis statistik deskriptif memperlihatkan bahwa sebagian besar masyarakat menyetujui Kegiatan Instalasi Pengolahan Air Limbah (IPAL) Komunal Berbasis Masyarakat dilaksanakan di masing-masing kecamatan. Hal ini dapat dilihat dari data temuan bahwa $97 \%$ responden (hasil penjumlahan dari $74 \%$ sangat setuju, $18 \%$ setuju, dan $5 \%$ agak setuju) dapat dikategorikan sebagai masyarakat yang menyetujui adanya kegiatan tersebut.

Kesimpulan dari pembahasan evaluasi respon masyarakat terhadap Kegiatan Instalasi Pengolahan Air Limbah (IPAL) Komunal Berbasis Masyarakat telah 
memenuhi indikator evaluasi. Masyarakat merasa terbantu dengan adanya perbaikan jaringan IPAL komunal di masing-masing kecamatan.

\section{b. Peran Masyarakat Terhadap Kegiatan Instalasi Pengolahan Air Limbah (IPAL) Komunal Berbasis Masyarakat}

Penilaian mengenai peran masyarakat terhadap Kegiatan Instalasi Pengolahan Air Limbah (IPAL) Komunal Berbasis Masyarakat digunakan untuk mengetahui gambaran sejauh mana tindak lanjut dari respon masyarakat terhadap Kegiatan Instalasi Pengolahan Air Limbah (IPAL) Komunal Berbasis Masyarakat. Peran yang dimaksud adalah segala bentuk keterlibatan masyarakat dalam menjalankan kegiatan pada masing-masing tahapan (perencanaan, pelaksanaan, serta operasi dan pemanfaatan).

Evaluasi variabel peran masyarakat dilakukan dengan melihat gambaran seberapa besar persentase responden yang berperan atau tidak dalam Kegiatan Instalasi Pengolahan Air Limbah (IPAL) Komunal Berbasis Masyarakat. Hasil evaluasi Kegiatan Instalasi Pengolahan Air Limbah (IPAL) Komunal Berbasis Masyarakat dengan menggunakan variabel peran masyarakat adalah sebagai berikut :

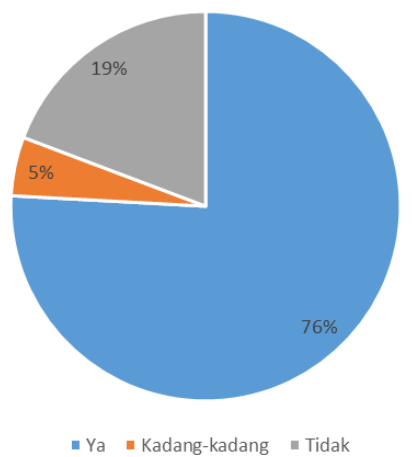

Gambar 5. Peran Masyarakat Terhadap Kegiatan Instalasi Pengolahan Air Limbah (IPAL) Komunal Berbasis Masyarakat

Hasil analisis statistif deskriptif menunjukkan bahwa sebagian besar responden berperan dalam Kegiatan Instalasi Pengolahan Air Limbah (IPAL) Komunal Berbasis Masyarakat. Sebanyak $76 \%$ reponden ikut berperan dalam kegiatan tersebut. Sisanya, 5\% responden hanya berperan di beberapa tahapan kegiatan saja dan $19 \%$ responden tidak ikut berperan dalam Kegiatan Instalasi Pengolahan Air Limbah (IPAL) Komunal Berbasis Masyarakat.

Kesimpulan yang bisa didapatkan dari evaluasi Kegiatan Instalasi Pengolahan Air Limbah (IPAL) Komunal Berbasis Masyarakat menggunakan vaiabel peran masyarakat adalah sudah memenuhi kriteria indikator evaluasi. Namun, peran masyarakat dalam Kegiatan Instalasi Pengolahan Air Limbah (IPAL) Komunal Berbasis Masyarakat hanya di beberapa tahapan dikarenakan beberapa anggota masyarakat beranggapan bahwa pemerintah tidak melibatkan masyarakat dalam proses pelaksanaan kegiatan.

3. Evaluasi Responsivitas Kegiatan Penanganan Sampah Meliputi Kegiatan Pemilahan, Pengumpulan, Pengangkutan, Pengolahan dan Pemosesan Akhir

a. Respon Masyarakat Terhadap Kegiatan Penanganan Sampah

Respon masyarakat terhadap Kegiatan Penanganan Sampah yang dimaksud adalah pernyataan setuju atau tidak setuju masyarakat terhadap kegiatan yang dilakukan di kecamatan mereka. Hasil evaluasi variabel respon masyarakat terhadap Kegiatan Penanganan Sampah disajikan dalam grafik berikut:

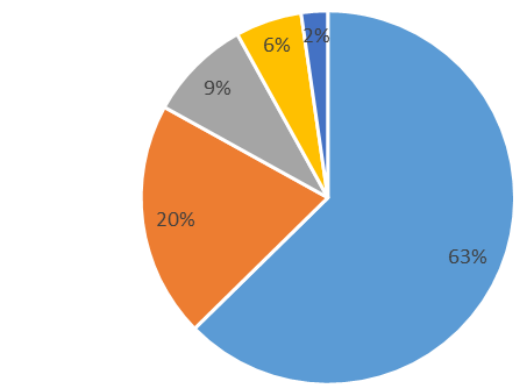

- Sangat Setuju - Setuju - Agak Setuju - Kurang Setuju - Tidak Setuju

Gambar 6. Respon Masyarakat terhadap Kegiatan Penanganan Sampah

Hasil analisis statistik deskriptif memperlihatkan bahwa sebagian besar masyarakat menyetujui Kegiatan Penanganan Sampah dilaksanakan di masing-masing kecamatan. Hal ini dapat dilihat dari data temuan bahwa $92 \%$ responden (hasil penjumlahan dari $63 \%$ sangat setuju, $20 \%$ setuju, dan $9 \%$ agak setuju) dapat dikategorikan sebagai masyarakat yang menyetujui adanya kegiatan tersebut.

Kesimpulan dari pembahasan evaluasi respon masyarakat terhadap Kegiatan Penanganan Sampah telah memenuhi indikator evaluasi. Masyarakat merasa terbantu dengan adanya penanganan sampah melalui bank sampah di masing-masing kecamatan. Selain menjadikan lingkungan kecamatan menjadi lebih bersih dan sehat, sampah dapat mengahasilkan nilai ekonomi untuk masyarakat.

b. Peran Masyarakat Terhadap Kegiatan Penanganan Sampah

Penilaian mengenai peran masyarakat terhadap Kegiatan Penanganan Sampah digunakan untuk mengetahui gambaran sejauh mana tindak lanjut dari respon masyarakat terhadap Kegiatan Penanganan Sampah. Peran yang dimaksud adalah segala bentuk keterlibatan masyarakat dalam menjalankan kegiatan pada masing-masing tahapan (perencanaan, pelaksanaan, serta operasi dan pemanfaatan).

Evaluasi variabel peran masyarakat dilakukan dengan melihat gambaran seberapa besar persentase responden yang berperan atau tidak dalam Kegiatan Penanganan Sampah. Hasil evaluasi Kegiatan Penanganan Sampah dengan menggunakan variabel peran masyarakat adalah sebagai berikut :

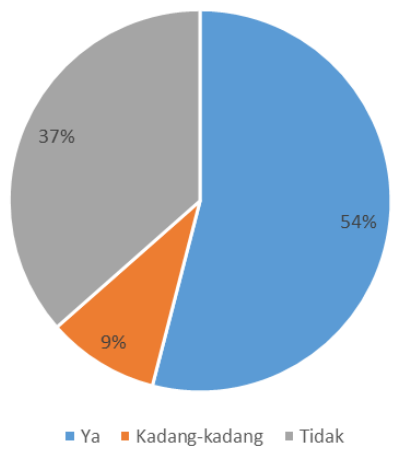

Gambar 7. Peran Masyarakat terhadap Kegiatan Sanitasi Total Berbasis Masyarakat

Hasil analisis statistif deskriptif menunjukkan bahwa sebagian besar responden berperan dalam Kegiatan Penanganan Sampah. Sebanyak 54\% reponden ikut berperan dalam kegiatan tersebut. Sisanya, $37 \%$ responden hanya berperan di beberapa tahapan kegiatan saja dan $9 \%$ 
responden tidak ikut berperan dalam Kegiatan Penanganan Sampah.

Kesimpulan yang bisa didapatkan dari evaluasi Kegiatan Penanganan Sampah menggunakan variabel peran masyarakat adalah sudah memenuhi kriteria indikator evaluasi. Namun, dengan melihat Kegiatan Penanganan Sampah melalui bank sampah yang diterapkan, cukup banyak masyarakat yang menyatakan hanya ikut di beberapa tahapan kegiatan. Hal ini dikarenakan banyaknya tahapan dalam proses penangan sampah melalui bank sampah.

Hasil Evaluasi Responsivitas Program Kabupaten Sehat di Kabupaten Blitar

Tabel 2.

Hasil Evaluasi Responsivitas Masyarakat terhadap

\begin{tabular}{|c|c|c|c|}
\hline Kegiatan & Indikator & Evaluasi & Penilaian \\
\hline $\begin{array}{l}\text { Kegiatan } \\
\text { Sanitasi } \\
\text { Total } \\
\text { Berbasis } \\
\text { Masyarakat }\end{array}$ & $\begin{array}{l}\text { Persentase } \\
\text { responden yang } \\
\text { menyetujui } \\
\text { program } \\
\text { kabupaten sehat }\end{array}$ & $\begin{array}{l}\text { Masyarakat } \\
\text { menyetujui adanya } \\
\text { kegiatan perbaikan } \\
\text { jaringan sanitasi di } \\
\text { masing-masing } \\
\text { kecamatan dan ikut } \\
\text { berperan. }\end{array}$ & Baik \\
\hline $\begin{array}{l}\text { Kegiatan } \\
\text { Instalasi } \\
\text { Pengolahan } \\
\text { Air Limbah }\end{array}$ & $\begin{array}{ll}\text { lebih } & \text { besar } \\
\text { daripada yang } & \text { yak menyetujui. }\end{array}$ & $\begin{array}{l}\text { Masyarakat } \\
\text { menyetujui adanya } \\
\text { kegiatan perbaikan } \\
\text { jaringan pengelolaan }\end{array}$ & Baik \\
\hline $\begin{array}{l}\text { Komunal } \\
\text { Berbasis } \\
\text { Masyarakat }\end{array}$ & $\begin{array}{l}\text { Persentase } \\
\text { responden yang } \\
\text { berperan terhadap } \\
\text { program }\end{array}$ & $\begin{array}{l}\text { limbah di masing- } \\
\text { masing kecamatan } \\
\text { dan ikut berperan. }\end{array}$ & \\
\hline $\begin{array}{l}\text { Kegiatan } \\
\text { Penangana } \\
\text { n Sampah }\end{array}$ & $\begin{array}{ll}\text { kabupaten } & \text { sehat } \\
\text { lebih } & \text { besar } \\
\text { daripada yang } \\
\text { tidak berperan. }\end{array}$ & $\begin{array}{l}\text { Masyarakat } \\
\text { menyetujui adanya } \\
\text { kegiatan } \\
\text { pengelolaan sampah } \\
\text { di masing-masing } \\
\text { kecamatan dan ikut } \\
\text { berperan. }\end{array}$ & Baik \\
\hline
\end{tabular}

Berdasarkan rangkaian evaluasi di atas ditemukan hasil penelitian bahwa responsivitas masyarakat terhadap Program Kabupaten Sehat di Kabupaten Blitar telah memenuhi kriteria responsivitas. Masyarakat memiliki respon yang baik terhadap seluruh kegiatan pada Program Kabupaten Sehat. Program Kabupaten Sehat yang diterapkan di Kabupaten Blitar sangat diharapkan oleh masyarakat untuk dapat memperbaiki kualitas hidup dari segi kesehatan.

Selain itu, peran masyarakat dalam pelaksanaan Program Kabupaten Sehat cukup baik. Sebagian masyarakat mau terlibat dalam kegiatan-kegiatan yang dilakukan di masingmasing kecamatan. Namun, masih ada beberapa warga yang belum berperan dalam Program Kabupaten Sehat dikarenakan akses terhadap infomasi mengenai kegiatankegiatan yang dilakukan masih terbatas. Selain itu, mereka juga masih bersifat pasif dengan menganggap suatu program yang dilakukan oleh pemerintah adalah tanggung jawab pemerintah itu sendiri.

\section{KESIMPULAN}

Berdasarkan hasil analisis data dan pembahasan maka dapat disimpulkan bahwa secara keseluruhan hasil evaluasi Program Kabupaten Sehat di Kabupaten Blitar dinilai dari kriteria responsivitas sudah memenuhi kriteria evaluasi.
Masyarakat memberikan respon yang baik terhadap program yang dilaksanakan di masing-masing kecamatan. Selain itu, masyarakat turut berperan serta dalam kegiatan-kegiatan di dalam Program Kabupaten Sehat. Namun, masih terdapat beberapa anggota masyarakat yang belum ikut berperan dalam Program Kabupaten sehat dikarenakan minimnya akses terhadap informasi terkait kegiatan yang dijalankan serta adanya anggapan bahwa program yang dilaksanakan adalah tanggung jawab pemerintah.

Rekomendasi yang diberikan adalah Pemerintahn Kabupaten Blitar selaku penanggung jawab dalam Program Kabupaten Sehat perlu melakukan sosialisasi yang baik kepada masyarakat terkait kegiatan-kegiatan yang dilaksanakan serta mengajak masyarakat untuk terlibat dalam proses perencanaan, pelaksanaan, serta operasi dan pemanfaatan.

\section{DAFTAR PUSTAKA}

[1] Widodo, J. (2008). Analisis Kebijakan Publik. Jakarta: Banyumedia.

[2] Bakir, S. (2009). Kamus Lengkap Bahasa Indonesia. Tangerang: Karisma Publishing Group.

[3] Islamy, I. (2009). Prinsip-prinsip Perumusan Kebijaksanaan Negara Jakarta: Bumi Aksara

[4] Arikunto, S. (2010). Prosedur Penelitian Suatu Pendekatan Praktik Edisi Revisi. Jakarta: Rineka Cipta.

[5] Arisandi, H. (2012). Buku Pintar Pemikiran Tokoh-tokoh Sosiologi. Yogayakarta: IRCiSoD.

[6] Nugroho, R. (2012). Public Policy. Jakarta: Gramedia.

[7] Dwiyanto, A. (2014). Mewujudkan Good Governance Melalui Pelayanan Publik. Yogyakarta: Gadjah Mada University Press.

[8] Sugiyono. (2011). Metode Penelitian Kuantitatif dan Kualitatif dan R \& D. Bandung: Alfabeta.

[9] Sugiyono. (2014). Metode Penelitian Pendidikan Pendekatan Kuantitatif, Kualitatif, dan R\&D. Bandung: Alfabeta. 